Est Ag 48 (2013) 19-46

\title{
La contribución de los Profetas al monoteísmo bíblico ${ }^{1}$
}

\author{
P. Luis Ángel Montes Peral
}

RESUMEN: En sus orígenes el monoteísmo no constituyó la esencia de la religión judía. El antiguo pueblo hebreo no fue monoteísta sino henoteísta: adoró al Dios vivo de Israel, pero pensó en la existencia de otros dioses, que protegían a los distintos pueblos y los acompañaban en sus avatares históricos. Los profetas, empezando por el gran Elías (s. IX a C.), por Amós y Oseas (s. VIII a. C.), y continuando por el Protoisaías, Jeremías y Ezequiel (siglos VIII-VI a. C.), contribuyeron de manera decisiva a alcanzar la fe en el uno y único Yahvé. Pero fue el Deuteroisaías (s. VI a. C.), el profeta de la incomparabilidad y trascendencia divinas, el mayor fenómeno teológico del Primer Testamento, el que puede ser considerado como el primer autor, propiamente monoteísta de la tradición bíblica, tanto en la exposición conceptual doctrinal como en la expresión lingüística.

PALABRAS CLAVES: Dios, henoteísmo, Elías, Deuteroisaías.

ABSTRACT: Monotheism did not constitute the essence of the Jewish religion in its origins. The ancient Hebrew people were not monotheistic but henotheistic: they worshipped the living God of Israel, but recognised the possibility of the existence of other gods that protected the different peoples and accompanied them through the stages of their history. The prophets, beginning with the great Elijah ( $9^{\text {th }}$ c. BC), Amos and Hosea ( $8^{\text {th }}$ c. BC), and then Proto-Isaiah, Jeremiah and Ezekiel $\left(8^{\text {th }}-6^{\text {th }} \mathrm{c}\right.$. BC), contributed decisively in the move towards faith in the one and only Yahweh. But it was the Deutero-

1 Conferencia pronunciada en el Estudio Teológico Agustiniano de Valladolid el día 15 de mayo de 2012, en el marco de un ciclo de conferencias sobre La Biblia y su contexto. Para su publicación se han añadido las citas bíblicas y la mayoría de las notas. 
Isaiah $\left(6^{\text {th }} \mathrm{c} . \mathrm{BC}\right)$, the prophet of divine incomparability and transcendence, the greatest theological phenomenon of the First Testament, who can be considered to be the first truly monotheistic author in biblical tradition, both in the exposition of doctrinal concepts and in linguistic expression.

KEYWORDS: God, henotheism, Elijah, Deutero-Isaiah.

Monoteísmo, sin más, es la enseñanza religiosa que sostiene la existencia de un solo y único de Dios. Niega de forma radical la posibilidad de existencia de los dioses. El monoteísmo como confesión y adoración de un único Dios con exclusión de los dioses, no puede ser considerado como un conocimiento puramente teórico ${ }^{2}$. Abordo un tema que tiene gran incidencia práctica, aunque a simple vista no lo parezca. De hecho, constituye una realidad viva, que afecta los principios religiosos, pero también la vida diaria. Configura la comprensión de la realidad de tal forma, que tiene hondas consecuencias en la cosmovisión de las personas y en el desenvolvimiento de las colectividades. Algo que deseo mostrar a lo largo de la exposición. Dejo a un lado los aspectos políticos ${ }^{3}$, bien interesantes por cierto, pero que desbordan el objetivo primero de mi trabajo. Sólo en alguna nota aludiré a ellos.

\section{Una distinción básica para empezar: henoteísmo y monoteísmo}

Coincido con Norbert LOHFINK, el conocido jesuita especialista en el Primer Testamento, profesor durante décadas en la Universidad Gregoriana

\footnotetext{
2 Para un conocimiento fundamental y comprehensivo de las religiones no cristianas, cf. M. Guerra Gómez, «Las religiones del mundo», en E. Bueno DE LA Fuente/ R. CALvo PÉREZ, ¡ABBA! Enciclopedia del Cristianismo Contemporáneo en España y Latinoamérica (Burgos 2011; Monte Carmelo) 946-988. El siguiente estudio nos brinda una excelente y honda introducción al monoteísmo, cf. A.A. V.V. «Monotheismus I. Religionsgeschichtlich II. Altes Testament III. Judentum IV. Systematisch-theologisch»: TRE 23, 233-262. En las páginas finales puede encontrarse una selecta bibliografía internacional.

3 Cf. el importante estudio de E. PETERSON, El monoteísmo como problema político. Con prólogo de G. URIBARRI (Madrid 1999; Trotta). Se trata de un extenso escrito, que se ha hecho clásico con el paso del tiempo, y que se publicó por primera vez en 1935 en Leipzig bajo el título «Der Monotheismus als politisches Problem». Más tarde se recogió en un libro de artículos suyos: «Theologische Traktate», publicado en 1951 por la editorial Kösel de Múnich (45-147). Contamos con una cuidada edición castellana: E. PETERSON, Tratados teológicos (Madrid 1966; Cristiandad). El pensamiento del autor suscita una serie de interrogantes prácticos, bien interesantes por cierto, que ponen de manifiesto la importancia del monoteísmo trinitario cristiano, que se distingue del monoteísmo sin más y del politeísmo. Suscita un buen número de cuestiones como éstas. ¿Cuál es la relación, dogmáticamente exacta, existente entre el cristianismo y el ámbito político? ¿En virtud de qué razones teológicas se establece tal relación?
} 
de Roma, cuando mantiene que «resulta problemático considerar el monoteísmo como la esencia del mensaje de Israel» ${ }^{4}$. Considerando los orígenes y el desarrollo de la religión judía, no nos queda más remedio que dictaminar que transcurrieron muchos siglos en la historia del pueblo judío, hasta que los hebreos fueron monoteístas en un sentido estricto. Nos puede sorprender tal dictamen, pero así fue en realidad. «El politeísmo está presente en la mayor parte de las Sagradas Escrituras» 5 .

Para comprender en su justa medida la afirmación anterior, conviene establecer una distinción básica. Una cosa es el henoteísmo, que lleva consigo, como consecuencia necesaria, la práctica de la monolatría y otra cosa, bien diferente por cierto, es el monoteísmo, en su sentido estricto, que nos permite mantener una concepción unitaria de todo lo creado y abogar por un único origen de la realidad existente con las repercusiones pertinentes, que tal principio establece. Desde Max MüLLER, un reconocido etnólogo alemán del siglo XIX, que acuñó el significado del término, se denomina «henoteísmo» la fe, existente en algunos pueblos, en la confesión de dioses únicos; dioses, que son considerados los mayores y más poderosos. Se profesa la creencia en la existencia de un dios, que está por encima de todos los demás. Se le conceden los más altos atributos, no superados por ninguna otra esencia divina, humana o cósmica. Se trata, por lo tanto, de una forma un tanto depurada de politeísmo. Sólo se adora a un dios fuerte, pero no se excluye la existencia de otros dioses. No estamos aún ante un monoteísmo estricto, aunque conduce a él ${ }^{6}$.

Algo así ocurrió en el modo de pensar y obrar del pueblo judío. Tuvo su Dios propio, con una identidad bien definida: Yahvé. Dio a conocer su nom-

${ }^{4}$ N. LoHFink, Unsere grossen Wörter. Das Alte Testament zu Themen dieser Jahre (Friburgo-Basilea-Viena 1977) 138: «Der Monotheismus andererseits ist so verstohlen, so spät und so sehr in Verbindung mit breiteren Umschichtugen im Bewusstsein der damaligen Menschheit ins Alte Testament hineingekommen, dass es fragwürdig erscheint, in ihm die Essenz der Botschaft Israels zu sehen».

${ }^{5}$ Ibídem, 128. Por eso no puedo estar de acuerdo con la tesis de que «no se puede hablar de una evolución hacia el monoteísmo en el interior de la fe de Israel, porque desde el momento en que Israel toma conciencia de ser el pueblo elegido por un dios, es prácticamente monoteísta» (E. JACOB: «Yahvé y los otros dioses», en Teología del Antiguo Testamento (BO 3; Madrid 1969; Marova) 66s. Tampoco coincido con la posición de F. ÁlvareZ, «Monoteísmo», en A. Díez Macho/ S. Bartina (dir.), Enciclopedia de la Biblia V (Barcelona 1963; Garriga) 303-308.

6 Max MüLLER, Vorlesungen über den Ursprung und die Entwicklung der Religion (Estrasburgo 1880; Trübner, sexta conferencia: «Über Henotheismus, Polytheismus und Atheismus»). Desde luego el henoteísmo constituye «el primer peldaño» hacia el monoteísmo. La expresión aparece por primera vez en el filósofo idealista F. W. J. SCHELLING en su obra: «Philosophie der Mithologie und der Offenbarung» (1842). 
bre en el Sinaí durante la época de Moisés $($ Ex 3,14) y desde sus inicios fue el exclusivo Dios, primero de las tribus hebreas y después del pueblo de Israel. La expresión «el pueblo de Yahvé» aparece 17 veces en el Primer Testamento en boca de Dios mismo, de sus portavoces y de los piadosos. Adquiere una gran significación en la conciencia nacional judía a lo largo de su historia, como manifestación de su identidad más propia. La expresión tiene su pleno sentido, cuando el mismo Yahvé habla, vinculándose a los suyos, y cuando el profeta habla en su nombre. También encontramos el término, cuando los fieles se dirigen a su Dios y cuando rezan ante su presencia mediante la expresión de un acto íntimo como pocos.

Este significativo hecho, cuya conciencia se expresa incluso en un lenguaje exclusivo, diferenciaba a Yahvé de los dioses de los demás pueblos. Los judíos apreciaban en su Dios unas altas prerrogativas, que los otros dioses no tenían, aunque pertenecieran a pueblos poderosos. Pero a pesar de todo, sus adoradores pensaban que había otros dioses menores protectores, como los venerados por los crueles asirios y por los odiados babilonios. Éstos también tenían existencia y hasta consistencia, aunque Yahvé era el más fuerte de todos. Ninguno de los dioses había vencido nunca a Yahvé. A su lado no tenía ningún dios menor, que le hiciera sombra.

Este pequeño estudio tiene como finalidad trazar, aunque sea con grandes pinceladas, el largo camino recorrido por los profetas, que fueron los máximos representantes en la adquisición del monoteísmo y cómo históricamente se logró implantar personal y comunitariamente la confesión de fe en un solo y único Dios. Lo que los cristianos confesamos sin dar lugar a las dudas ya desde los orígenes más primitivos, los judíos tardaron muchos siglos en asimilarlo. Conviene recordar que el cristianismo tiene sus raíces en el judaísmo y que nuestra religión se aprovechó de muchas de las conquistas de la fe bíblica. Una de las más importantes es ésta.

\section{Estado de la cuestión: sacerdotes, profetas y sabios; sobre todo profetas}

A lo largo de su historia, hubo en Israel tres admirables grupos, influyentes representantes de lo más granado de la sociedad judía del primer milenio antes de Cristo. Jugaron una importancia excepcional en la formación de la religión judía, tanto en la fijación de su espiritualidad como en la composición de los libros sagrados. Estos tres grupos, que los judíos tomaron en sus orígenes de otros pueblos y religiones, los llamaron: kohenim, hakamim y nabiim. Expresado en román paladino: los sacerdotes, los sabios y los profetas. 
No cabe duda que los sacerdotes y sabios contribuyeron de forma eminente a la conquista del monoteísmo. Pero fueron los profetas $^{7}$, con el testimonio de vida y con sus variados oráculos, con su teología y espiritualidad los auténticos artífices de la fe monoteísta, los que dieron el impulso mayor y final a la confesión monoteísta; los que incluso mejor expresaron su contenido en el lenguaje. Llenos de Dios y apasionados de los hombres, precisaron la realidad divina con un rigor admirable y fueron los portavoces autorizados para hablar en nombre y en lugar de Dios delante y a favor del pueblo. Aquí me voy a referir exclusivamente a ellos.

Algunos fueron sacerdotes ${ }^{8}$ y muchos de ellos tienen su sitio privilegiado también entre los sabios. Me centro sobre todo en los profetas escritores, que compusieron libros del Canon bíblico y que, en lo que aquí nos interesa, se extienden desde el siglo VIII hasta el final de la Cautividad de Babilonia en el siglo VI a. C. (587-538). Amós y Oseas, Jeremías y el Deuteroisaías, a ellos me voy a referir ${ }^{9}$, fueron los que influyeron de forma más decisiva en la estructuración del credo bíblico definitivo: un solo Dios, una sola Ley y un solo Templo. También me voy a referir a un profeta no escritor, en concreto a Elías, que tuvo también su gran aportación. Con él quiero empezar ahora.

\section{El movimiento del «solo Yahvé», patrocinado por Elías ${ }^{10}$}

Elías pasa por ser uno de los mayores profetas de la Primera Alianza. Es celebrado por los judíos como pocos. En el Libro del Eclesiástico el elogio que

7 Para un conocimiento exacto de lo que significa el profetismo en el Primer Testamento, cf. L. Monloubou, Profetismo y profetas. Profeta ¿quién eres tú? (Madrid 1971; Fax); A. NEHER, La esencia del profetismo (Salamanca 1975; Sígueme); W. BRUEGGEMANN, La imaginación poética (Santander 1986; Sal Terrae); J. L. SICRE, Los profetas de Israel y su mensaje (Madrid 1986; Cristiandad); J. AsuRMEnd, El profetismo (Bilbao 1987; Desclée de Brouwer); E. BEAUCAMP, Los profetas de Israel o el drama de una alianza (Estella [Navarra] 1988; Verbo Divino); J. L. SICRE, Profetismo en Israel. El profeta, los profetas, el mensaje (Estella [Navarra] 1992; Verbo Divino).

8 Cf. A. GonzÁlez Núñez, Profetismo y Sacerdocio (Madrid 21969; Casa de la Biblia). Este estudio analiza las complejas relaciones entre el profetismo, el sacerdocio y la monarquía. Atiende sobre todo a los aspectos históricos y teológicos.

9 Para abreviar mi reflexión, dejo a un lado otras figuras importantes como el Protoisaías y Ezequiel. Lo hago porque, según mi modo de entender las cosas, su aportación en este campo no fue tan decisiva como los anteriores.

10 Para un acercamiento a la figura de Elías, cf. J. BRIGHT, La historia de Israel (Bilbao 31970; Desclée de Brouwer). Puede consultarse también la bibliografía de las páginas 499-503, sobre todo el epígrafe: «Introducción al mensaje y a la teología del Antiguo Testamento» (501s); G. vON RAD, Teología del Antiguo Testamento II. Teología de las tradiciones proféticas 
su autor hace sobre su reconocida y admirada persona no puede ser más alto. Es descrito con metáforas lapidarias: «Como un fuego, su palabra quemaba como antorcha» (Eclo 48,1-11). Explícita e implícitamente aparece con cierta frecuencia también en los Evangelios, más que ningún otro profeta. Mateo lo identifica con Juan el Bautista (Mt 11,14). En círculos populares algunos pensaban que el mismo Jesús era el «Elías redivivus» (Mc 8,28 par). En la Transfiguración, junto con Moisés, acompaña a Jesús (Mc 9,4). Estas dos descollantes personalidades representan muy bien al Primer Testamento como el pueblo de la Ley y de la Palabra.

La importancia de Elías y de su discípulo Eliseo queda perfectamente constatada en los Libros de los Reyes. Desde 1 Re 17 hasta 2 Re 8 las tradiciones en torno a estos dos formidables atletas de la fe en Yahvé prevalecen por encima de los acontecimientos políticos, liderados por los reyes. La actividad más significativa de Elías coincide con el tiempo de Ajab, rey de Israel, casado con la princesa fenicia Jezabel. Es durante su reinado, cuando las gestas de Elías adquieren mayor renombre ${ }^{11}$. El matrimonio real, a quien nuestro profeta combatió hasta las últimas consecuencias, dejó hondas huellas tanto en la política como en la vida religiosa de su tiempo. Pero más fuerte aún fue el influjo de nuestro profeta.

Jezabel logró que Ajab adorara a su dios Baal, una famosa divinidad que los fenicios veneraban, sobre todo en su forma local, como la suprema de las divinidades de sus estados-ciudad. Para satisfacer los deseos de su mujer, Ajab incluso erigió un templo en honor del dios en Samaría, como santuario oficial no sólo para la familia real, también para una parte de su extensa liga de estados. A este culto hay que añadir el tributado a los baales, ídolos menores emparentados con Baal, verdaderos dioses de la fecundidad de los pueblos cananeos, muy venerados en la religiosidad cosmo-vital de la región. La religión oficial de la corte amenazaba una apostasía a gran escala del yahvismo.

de Israel (Salamanca 1972; Sígueme) 30-42; S. HERrmanN, Historia de Israel (Salamanca 1979; Sígueme) 272-279. Pueden verse también los numerosos comentarios a los Libros de los Reyes. Una introducción pedagógica a nuestro profeta puede verse en R. GoNZÁLEZ BLANCO, Los profetas traductores de Dios (Salamanca 2004; San Esteban), cap. III: «Elías el profeta de fuego, Eliseo el Taumaturgo del Antiguo Testamento» (51-68); E. J. MARTínEZ GonzÁLEZ, «Elías, profeta»: Pliego de Vida Nueva 21 oct. (2000) 23-29. Una amplia bibliografía internacional puede encontrarse en: H. SEEBASS, «Elia I»: TRE 9, 501s.

11 El mismo nombre de Elías tiene una gran significatividad en su lucha contra la apostasía israelita. Aparece en el texto masorético en dos formas, que podemos considerar complementarias: Eliyahu, con el significado «mi Dios es Yahvé» y Eliyah, que puede traducirse así: «Yahvé es Dios». Ambos significados sitúan a Yahvé en el centro de la vida del profeta. 
Dejando a un lado particularidades sobre el culto tributado a este dios mayor, conviene indicar que en este tiempo había dos clases de profetas: los llamados hermanos profetas o «profetas de Yahvé»12 y los que estaban al servicio de Baal. Jezabel, decidida como pocas, se puso de parte de los segundos y persiguió a los primeros, de un modo muy especial a Elías, el más destacado de los profetas de Yahvé. Los yahvista leales, partidarios incondicionales de Elías, fueron también perseguidos muy pronto, recurriendo la oficialidad, con el paso del tiempo, a medidas cada vez más crueles y exterminadoras.

Pues bien, este sobresaliente profeta de Yahvé, proveniente de Tisbé en la región de Galaad (1 Re 17,1), que obró en diversos lugares de Israel, pero nunca en Judá (en Judá no conocemos conflictos con la religión de Baal), mantuvo una lucha a brazo partido contra la idolatría reinante en el norte, en la que estaban implicados sus hombres más representativos, sacerdotes, funcionarios importantes, no sólo el rey y la corte, como ya hemos indicado. Ante tanta infidelidad no podía por menos de producirse, con Elías al frente, una poderosa contracorriente, procedente de los círculos fieles a Yahvé, que se consideraban como su propiedad exclusiva. El grado de su oposición no pudo ser más aguerrido y alcanzar cuotas más violentas. Es bien conocido el famoso episodio de Elías y los profetas de Baal en el Monte Carmelo, que acabó en una espantosa carnicería. En el fragor de la lucha enconada contra los partidarios de Baal, el profeta clama a su Dios así:

«Señor, Dios de Abraham, de Isaac y de Israel que se sepa hoy, que tú eres Dios de Israel, que yo soy tu siervo y que por orden tuya hago yo todo esto»

$(1 \operatorname{Re} 18,36)$.

No había alternativa: $O$ Yahvé o Baal. Elías rechaza a Baal, porque no se comporta como un dios vivo y emplaza al pueblo a elegir de nuevo a Yahvé, pasando a cuchillo a los sacerdotes de Baal, ganada la prueba. Para hacer más eficaz su rechazo frontal, reunió en torno suyo a un numeroso grupo de adeptos, los denominados adoradores de Yahvé y logró su separación del resto del país. Ignoramos el origen de este movimiento. Tampoco queda muy clara toda

12 «Los profetas hebreos se agruparon en clanes de hermanos profetas, que buscaban la palabra de Dios y se esparcen pronto por todo el territorio: Guibeá (1 Sm 10,10), Ramá (1 Sm $19,20)$; Samaría $(1 \operatorname{Re} 22,10)$, Betel $(2 \operatorname{Re} 2,3)$, Jericó $(2 \operatorname{Re} 2,5)$ y Guilgal $(2 \operatorname{Re} 4,38)$. Este movimiento profético sufrió una seria persecución a manos de la reina Jezabel y cien hermanos -lo que nos da idea de lo numeroso del grupo-fueron protegidos por el piadoso Abdías, mayordomo real $(1 \mathrm{Re} 18,4) »$ (E. J. MARTínEZ GonZÁLEZ, Elías, profeta, 25). 
la razón de la separación. ¿Fue sólo por motivos religiosos o hubo por medio otros motivos en juego? Lo cierto es que este movimiento, que tenía como lema de campaña «Sólo Yahvé», se encuentra en los orígenes mismos del largo proceso hacia un Dios uno y único.

La total identificación con Yahvé, el Dios tronante del Sinaí, que no tolera rival (Ex 19-20), y el abierto rechazo de los dioses aspirantes, lleva en la mente del profeta Elías y en la de sus partidarios a una marcada exclusividad de Yahvé, que prescinde de la existencia de otros dioses y que en su momento llegó a cristalizar en el monoteísmo. Tanto Elías como sus ardientes seguidores nada querían saber del resto de los dioses inútiles e inanes, como se había mostrado en el Monte Carmelo (18,20-40). Les negaban el pan y la sal. Consideraban su misma existencia, en caso de tenerla, como negativa por entero, al menos para ellos. El conflicto entre Yahvé y Baal debía decidirse, sin duda alguna, a favor del primero y en la aniquilación de los baales.

La reina furiosa persiguió a muerte al profeta, que tuvo que ser ocultado para poder salvar la vida (1 Re 19). Aquélla buscaba por todos los medios aislar al Dios judío, extraño a sus sentimientos religiosos y contrario a sus intereses políticos, y acabar con Elías. Asimismo pretendió exterminar a sus seguidores sin poder conseguirlo. El profeta pasó momentos muy amargos, hasta el punto de querer morir $(1 \operatorname{Re} 19,4)$. Pero no cedió ni un ápice en su lucha. Con inflexible severidad luchó por el culto tradicional sin interferencias espurias, que pudieran poner en peligro la soberanía de Yahvé sobre su pueblo y la ruptura de la Alianza. Para Elías Baal era como si no existiese. Defendió como nadie la tesis, recibida por la tradición, de que Israel sólo pertenecía a Yahvé. «El marginado en el mundo de los dioses es el Dios de los marginados»13.

Ayudado por un buen número de adeptos y patrocinado por sus seguidores consiguió que el movimiento se convirtiera en un movimiento significativo en el reino de Israel, que fue el espacio palestino donde actuó con la mayor energía. Con palabras de fuego y planteamientos radicales mantuvo en vilo a los adoradores de los dioses cananeos, con los que no tuvo miramiento alguno. Sólo se podía tributar culto a Yahvé. Nadie más era digno del honor sumo, fuera quien fuera. El movimiento también abominaba de los hebreos, que se apartaran de la pureza de la fe recibida. Había que adorar únicamente a Yahvé.

Después de Elías y Eliseo, los combatientes por la causa de Yahvé se mantuvieron, aunque se redujo en número, ya que las circunstancias no les

13 B. LANG (dir.), Der einzige Gott (Múnich 1981) 61, citado por H. VORGRIMLER, Doctrina teológica de Dios (Biblioteca de teología 10; Barcelona 1987; Herder) 59. 
eran propicias y el entusiasmo inicial fue cediendo con el paso del tiempo y la desaparición de su gran protector. Volvió a resurgir con extraordinaria fuerza en la época del piadoso rey Josías (641-609), que intentó imponer una reforma religiosa en sus dominios, aunque obtuvo escasos resultados. Como consecuencia de ella se reformó significativamente el culto, centralizándose en el templo de Jerusalén. Se hizo desaparecer de su ámbito sagrado los símbolos a cultos extraños y sobre todo se clausuró el burdel, que para vergüenza de los piadosos aún se mantenía bajo el amparo del templo. Los santuarios rurales fueron clausurados. Entre los profetas, que apoyaron el movimiento hay que mencionar sobre todo a Sofonías, también a Jeremías ${ }^{14}$.

Despojado de radicalismos innecesarios, de él salió el Santo Resto y, más tarde, los pobres y humildes, que ponían toda su entera confianza en Yahvé (Sof $2,3 ; 3,12 s)^{15}$. Más allá de su desenvolvimiento histórico nos interesa destacar aquí que ese contra-movimiento, que tuvo su momento de auge en la alternativa planteada por Elías al culto idolátrico de su tiempo, supuso el primer paso eficaz hacia el monoteísmo. Se trata de una especie de monoteísmo de combate, que deja a un lado cualquier tipo de planteamiento teórico. Sale más de las vísceras que de la razón. Depende más de sentimientos nacionalistas que de una reflexión ponderada y de una vivencia equilibrada, despojada de fanatismo.

\section{Amós, el profeta de la justicia social y Oseas, el profeta del amor y la mise- ricordia divina ${ }^{16}$}

El monoteísmo teórico tiene su origen más destacado en los dos grandes profetas clásicos del reino del norte, representantes genuinos del período asi-

14 Cf. H. Vorgrimler, Doctrina teológica de Dios, 60. Con todo conviene precisar que Jeremías no se unió explícitamente a la reforma de Josías. El rey con buena intención, pero con pésimos métodos, quiso imponerla a la fuerza y el gran profeta no estaba de acuerdo con semejante procedimiento. La verdadera reforma sale del interior, del corazón renovado. De ahí que anuncie para el futuro una alianza nueva: «Vienen días, oráculo del Señor, en que yo sellaré con el pueblo de Israel y con el pueblo de Judá una alianza nueva» (Jr 31,31). "Pondré mi ley en su interior; la escribiré en su corazón; yo seré su Dios y ellos serán mi pueblo» (Jr 31,33).

15 Para Sofonías, el profeta de la pobreza espiritual, se salvará un Resto, formado por el auténtico Israel $(3,14)$, depositario de las promesas divinas de salvación $(2,7-9)$ y practicantes del bien, de la verdad y de la justicia, $(3,13)$. Quizá su aportación más original, y por la que más se le conoce en los ambientes bíblicos, está en haber considerado al Santo Resto como «el pueblo de los pobres», dando al término pobre (= anî) un sentido netamente religioso.

16 No conozco ningún estudio que aborde monográficamente el tema del monoteísmo en estos dos profetas. Los muchos comentarios existentes a estos profetas, sin embargo, contienen algunos puntos donde tratan el tema, aunque sin demasiada profundidad. Sobre Amós 
rio: Amós y Oseas, que ejercieron su misión en el siglo VIII a. C. Ambos reivindican una religión depurada, que confiese y adore al Dios de los padres como al único Dios. Lo esencial de la fe de Israel no consiste en haberse convertido en la religión del estado, sino en la relación sin par y entrañable existente entre Yahvé y el pueblo de la Alianza. Una relación, en la que el pueblo judío por desgracia no estuvo casi nunca a la altura de las circunstancias.

4.1. Amós de Tecoa, nacido en el reino del sur, misionó por mandato divino en el reino del norte. Alzó su voz contra los ricos para ponerse al lado de los pobres y servir a sus intereses, tan desprotegidos en aquellos tiempos de prosperidad y libertinaje. Efectivamente, su misión coincide con un momento de esplendor territorial y económico para los dos reinos; pero también de relajamiento religioso, decadencia moral y olvido de la Alianza. Con un exigente mensaje teológico, critica el lujo despreocupado de los pudientes $(6,1-14)$ y de sus mujeres $(4,1-3)$ y el comportamiento pecador del pueblo en general $(2,4-$ $3,15)$, con los ciudadanos de Israel al frente $(9,9 \mathrm{~s})$. Se convierte en el protector de los marginados de la sociedad y en el denunciador de las fuertes injusticias existentes en ella. Para ser fiel a la palabra de Dios y a su tarea tiene la valentía de encararse con el rey $(7,11)$, con los sacerdotes $(7,14 \mathrm{ss})$ y con los grandes del reino (3,14-15).

Amós es fuerte y reiterativo en las críticas sociales y en la denuncia de las falsas seguridades del pueblo judío y más bien parco en la presentación de perspectivas de salvación. Le duelen las escandalosas diferencias entre pobres y ricos $(3,11-15 ; 6,4-8)$. Grita sin desmayo contra la opresión, que deben soportar los débiles y desamparados $(4,1 ; 5,10-12)$; echa en cara la rapacidad de los poderosos $(3,9-10)$; la tiranía de los acreedores $(2,6-8 ; 5,11)$; la avaricia y despreocupación de los comerciantes $(8,4-6)$; la venalidad de los jueces $(2,6$; 5,10-16). Está plenamente convencido que el régimen imperante está corrompido por completo.

Los reproches contra el culto fastuoso y vacío son constantes e insistentes (3,14;4,4-5; 5,4-6;5,21-27). Y así denuncia: Los altares de Bethel $(3,14)$; los sacrificios infames y los pecados incesantes de los santuarios de Bethel y Guilgal $(5,5-6 ; 4,4)$. Según nuestro profeta, el «jbasta ya!» de Dios contra el culto idolá-

y Oseas existen buenos estudios. Baste aquí mencionar, el estudio conjunto, bien trazado pedagógicamente, de: J. M. Asurmend, Amós y Oseas (CB 64; Estella [Navarra] 1989; Verbo Divino). En las páginas 53s puede encontrarse una selecta bibliografía sobre comentarios y presentación de conjunto en torno a ambos profetas. En estas mismas páginas, sobre todo en la 54, tenemos también una bibliografía complementaria en castellano y francés sobre ambos profetas. Para la bibliografía internacional, cf. L. MARKERT, «Amos/ Amosbuch»: TRE 2, 485487; J. JEREMIAS, «Hosea/ Hoseabuch»: TRE 15, 596-598. 
trico e inane, que no va acompañado de justicia y derecho, es tan radical y definitivo que tiene la fuerza de un juramento inapelable $(4,2.6-7 ; 6,8-11)$.

En Amós, aunque mantenga aún la existencia de los dioses, encontramos una clara tendencia hacia el monoteísmo, como lo descubrimos en estas constataciones teológicas:

- Confiesa a Yahvé como Dios todopoderoso $(3,13 ; 9,5)$ y lo presenta como el Señor de la naturaleza y de la historia. Yahvé no tiene historia, aunque crea los procesos históricos e interviene decisivamente en ellos.

- Dirige la historia, como queda claro en los oráculos contra las naciones (1,3$2,3)$, y nada puede oponerse a sus sabios designios $(2,4-16 ; 9,11-15)$.

- Controla de forma exclusiva las fuerzas de la creación y domina los procesos cósmicos (4,6-11; 8,8-9; 9,5-6).

- Tiene providencia de su pueblo $(5,4.14-15)$ y se sitúa al lado de los descendientes de Jacob (9,5-10).

El conjunto de todas estas afirmaciones teológicas pone de manifiesto, que ante el poder omnímodo divino ceden por completo el resto de los poderes, por altos que sean y por adoradores poderosos que sirvan a sus intereses. Cuando se compara a Yahvé con los de otros dioses es para ensalzar al primero y denigrar a los segundos. Yahvé engrande la existencia del pueblo elegido, los dioses envilecen su trayectoria histórica. Exige derecho y justicia de su pueblo $(5,24)$, dejando a un lado «imágenes de astros divinizados, ídolos que os habéis fabricado» $(5,26)$. Amós articula la fe en un solo Dios de manera clara y en contraposición con los dioses.

4.2. Oseas, probablemente el único profeta nacido en el reino del norte, se acredita como uno de los más grandes profetas y puede considerarse con toda la razón como uno de los mayores poetas bíblicos y de la literatura universal. Su contribución al monoteísmo pasa por la afirmación teológica precisa, pero resplandece sobre todo por la bellísima expresión formal. Oseas entendía las relaciones de Yahvé con Israel como las mantenidas por un marido con su esposa. Exigían exclusividad, reciprocidad y, sobre todo, fidelidad. Anuncia la entrañabilidad del amor divino en relación con su pueblo pecador. La tragedia de éste consiste en que no corresponde a ese amor insondable, apasionado y regenerador.

No podemos detenernos a mostrar los tonos arrebatadores de ese amor divino, porque hemos de centrarnos en el tema del monoteísmo. Su teología contiene reflexiones, bien íntimas, sinceras y certeras: Yahvé es el Dios exclu- 
sivo de Israel $(13,4)$, a quien éste ha abandonado $(3,5 ; 4,6.12)$. Es el único Dios, ya que los baales cananeos no son nada, sino hechura humana $(8,4-6$; $13,2)$. Por eso, nuestro profeta rechaza el culto a las imágenes $(10,2.5 \mathrm{y}$ los textos anteriores). Su lucha además se extiende a la prostitución sagrada, mantenida en el mismo templo de Jerusalén. El Dios único es el santo $(12,1)$, el absolutamente otro, separado del hombre pecador:

«Porque yo soy Dios, no un hombre;

en medio de ti soy el Santo

y no me complazco en destruir» $(11,9)$.

Dios es fiel, el hombre infiel; Dios no miente, el hombre engaña:

«Efraín me rodea de mentiras,

$y$ de fraudes el pueblo de Israel» $(12,1)$.

Dios es amor, el hombre se comporta como un verdadero egoísta, y lo que aún es peor, como ingrato, que va detrás de otros dioses, como la mujer. adúltera. Ante la insensibilidad de su pueblo Yahvé se queja amargamente

«Pero cuanto mejores eran los pastos

y más satisfechos quedaban,

más se engreía su corazón

$y$ se olvidaron de mí» $(13,6)$.

Dios permanece en sus designios de salvación, porque es «el único salvador» $(13,4)$, pero el hombre se aparta de la salvación ofrecida con tanto amor y ternura, como un verdadero Padre con su hijo (cf. 11,1ss). Vista esta antología de textos, comprobamos cómo Oseas está poniendo bases firmes del monoteísmo teórico con sus acertadas expresiones lingüísticas, que dejan adivinar a un personaje, dotado de una gran sensibilidad creativa. Llevado además de una espiritualidad fuera de lo común, que sabe que todo se lo debe al único Yahvé, deja a un lado a los dioses y los critica con dureza. Creer en ellos sólo es fuente de desdichas para Israel.

\section{Jeremías, grande entre los grandes profetas ${ }^{17}$}

Pasamos a Jeremías, el profeta que tanto se parece a Oseas y que sigue sin duda su estela teológica y sus tonos monoteístas, radicalizándolos aún más

17 Para una bibliografía internacional exhaustiva, cf. S. HERRMANN, «Jeremia/ Jeremiabuch» en TRE 16,582-586. Una bibliografía bastante completa en castellano, que nos 
con sus ardorosos acentos intimistas. Jeremías se alza como un coloso de la confianza en Yahvé. Destaca entre los mayores profetas de todos los tiempos y como uno de los pocos genios religiosos de la historia de la humanidad. Perteneció, como quizás también Oseas, a la tribu de Benjamín, en el ámbito entonces, en el que probablemente nació el yahvismo. Por eso no nos tiene que extrañar que en esta tribu, de modo semejante a la de Efraím, se cultivaran con especial esmero las tradiciones, específicamente hebreas, del Éxodo y de la Alianza del Sinaí, distintas del resto de las tradiciones judaicas. Y en el coherente desarrollo de esos planteamientos religiosos su mensaje se acerca ya a un monoteísmo bien preciso.

Hemos afirmado que Jeremías es deudor del acerbo espiritual de los suyos. Por eso habla con frecuencia de la salida de Egipto y de la liberación realizada con brazo fuerte por Yahvé con los padres del pasado. Con tonos enternecedores se refiere a la Alianza establecida entre Dios y los israelitas y a la posterior conquista de la Tierra Prometida. Estos mismos temas aparecen en la tradición deuteronomista, que también influyó decisivamente en nuestro profeta. Pero el profeta va más allá en sus afirmaciones, algunas de ellas de una afectividad insuperable ante su Dios. La Alianza con Yahvé supone una relación muy especial con su pueblo, cuya validez permanece, de manera muy parecida a lo que se da en la alianza con la naturaleza (31,34-37; 33,20-22.25s).

No puedo detenerme, como quisiera, a detallar de forma minuciosa la gran contribución de Jeremías al monoteísmo. Baste con decir que, en consonancia con el planteamiento descrito, usa tres clases de argumentos para cimentarlo: unos sacados de la tradición, otros de la razón y otros de la moralidad. Me conformo con presentar aquí el tenor de su argumentación y algunos admirables textos, que suenan ya monoteístas y ofrecen su cuño característico.

\subsection{Argumentos de la tradición y vuelta a los orígenes}

Jeremías recurre con gran fuerza evocadora a los primeros tiempos, a los días del desierto, cuando las tribus judías experimentaban el amor divino (2,13). La fidelidad a Yahvé fue la prueba de su consistencia y felicidad (7,22-23).

permite integrar a Jeremías en su contexto político, social, cultural y sobre todo religioso, puede verse en: J. M. ABREGo DE LACY, Jeremías. Texto y comentario (El mensaje del Antiguo Testamento 13; Madrid 1993; Casa de la Biblia) 29s. Ha aparecido también en: Id, «Jeremías», en S. Guijarro/ M. Salvador (dir.), Comentario al Antiguo Testamento II (Madrid 21997; Casa de la Biblia). Puede completarse con G. Fischer, El libro de Jeremías (Guía Espiritual del AT; Madrid 1996); B. BozAK, «Jeremías», en W. FARMER y otros (dir.), Comentario Bíblico Internacional (Estella [Navarra] 1999) 911-946. 
Pero la tragedia de los judíos de su tiempo consiste en que no han sido fieles al pacto con Dios, han profanado de forma horrenda sus principios más sagrados. La vida religiosa y moral de su época se caracteriza por la ruptura con el amor primero, por el insensato abandono de la tradición original. Su última desgraciada historia ha constituido un trágico abandono de Yahvé y la vuelta a otros dioses $(1,16 \mathrm{~s} ; 2,5-19 ; 5,7)$, que les está llevando al desastre. Expone estas ideas con gran fuerza y reitera sus razonamientos una y otra vez:

"Así dice el Señor:

¿Qué falta encontraron en mí

vuestros antepasados para alejarse de mí?

Siguieron a dioses vanos

$y$ acabaron siendo vanidad» $(2,5)$.

«¿Acaso algún pueblo cambia de dioses?

-y eso que no son dioses-

Pues mi pueblo ha cambiado

su gloria por dioses inútiles» $(2,11)$.

«Tu maldad te castiga, tu infidelidad te condena.

Experimenta y aprende qué doloroso

$y$ amargo es abandonar

y no honrar al Señor tu Dios» $(2,19)$.

En una escena impresionante (5,1-31) Yahvé se encara con su pueblo y en un momento concreto repite su queja con una amargura sangrante:

«Tus hijos me han abandonado,

juran por dioses que no existen» $(5,7)$.

Yahvé tiene consistencia, se preocupa y ocupa de los suyos, pero los dioses sólo son «soplos de viento», vanidad en toda regla. No ofrecen fuerza alguna, se disuelven en la nada. De hecho no tienen poder alguno y no pueden ayudar. Pero a pesar de las pruebas suministradas, la rebelión de los judíos adquiere matices tremendos: han sido los propios pastores del pueblo, los que se han rebelado contra Yahvé $(2,8)$, desenmascarando así a los profetas y sacerdotes (5,30-31). Ha sido todo Israel, quien ha apostatado (3,6-12), sus miembros se han convertido en «hijos apóstatas» $(3,22)$. Han cerrado sus oídos e incluso se burlan de la palabra del Señor $(6,10)$. El espectáculo no puede ser más tremendo: «Es espantoso y horrible lo que sucede en este país» $(5,30)$.

En esta abominable traición, han participado por igual Israel y Judá $(5,11)$. Se han comportado como mujeres pérfidas, que han cometido la felo- 
nía de traicionar a su buen marido de la forma más vil $(3,20)$. El profeta identifica este adulterio con la búsqueda engañosa de dioses extraños $(3,13)$. El pueblo de Yahvé se entrega a los dictados idolátricos, cometiendo prostitución y adulterio $(3,9)$.

Pero Dios es compasivo $(3,11)$, su enfado no dura siempre $(3,11)$ y es tiempo propicio de conversión. Los primeros capítulos del libro, que coinciden con su primera actividad, están llenos de llamadas a la conversión, a la vuelta a los orígenes, a recuperar el abandonado amor primero: $3,1-5 ; 3,22 \mathrm{ss}$; 5,20-22. Conversión también a los semejantes necesitados $(7,5-6 ; 22,13 \mathrm{ss})$, entre los que se encuentran los esclavos, que han de ser liberados $(34,8 \mathrm{ss})$. Pero todo en vano. Por eso van a venir los enemigos del norte, los babilonios, que asolarán a Judá como en su día los asirios acabaron con Israel (cap. 5 y 6). Por no cumplir la Alianza y adorar a dioses extraños, Jerusalén va a ser destruida: «muchos pasarán junto a esta ciudad, y cuando se pregunten: ¿por qué ha tratado así el Señor a esta gran ciudad? Les responderán: 'Porque abandonaron la alianza de Señor, su Dios, para adorar y dar culto a otros dioses'» $(22,8 \mathrm{~s})$. Dioses que no dejan de ser naderías conformadoras de infortunios, sin ninguna capacidad para dar auténtica vida. La confianza en ellos supone la mayor de las tragedias.

\subsection{Argumentos de razón ${ }^{18}$}

En Jeremías, como acabamos de ver, aletea ya un claro monoteísmo: los dioses no son nada. Judá se ha pervertido lastimosa y trágicamente, cambiando el «todo» que es Yahvé por la «nada» que son dioses, ídolos y baales. Así de grave es su apostasía, de la que sólo él parece ser realmente consciente en Judá. Delimita perfectamente los campos y en nombre de la razón guía a los judíos hacia la verdad de la fe yahvista (2,26-28). He aquí sus críticas: Israel ha llegado a prostituirse y cometer adulterio con la piedra y el leño $(3,9)$. Los judíos han quemado incienso y se han postrado ante las obras de su manos $(1,16)$.

Está perfectamente claro que todos esos dioses de pacotilla, no pueden socorrer de verdad, prevenir ante la desgracia $(2,28)$. Son aljibes «agrietados», «sin agua», en contraposición con Yahvé que es «fuente de agua viva» $(2,13)$. Son seres «inútiles» $(2,11)$. En definitiva hay que considerarlos vanidad $(2,5)$, vaciedad $(8,19)$, ilusión pura y simple. Sin embargo Dios, además de ser el origen de la vida $(2,13)$, escruta y penetra en lo más íntimo de los pensamientos

18 Cf. H. COHEN, La religión de la razón desde las fuentes del judaísmo (Barcelona 2004; Anthropos). 
humanos, sin que nadie pueda esconderse ante su presencia $(23,23 \mathrm{~s})$. Es Todopoderoso, omnipresente y omnisciente.

Jeremías contrapone al Señor con los ídolos, contemplando la creación: "Los dioses que no han hecho ni el cielo ni la tierra desaparecerán de la tierra $y$ de debajo del cielo» $(10,11)$.

"No es así el "Lote de Jacob"

Porque él es el creador de todo,

Israel es la tribu de su heredad;

Su nombre es el Señor todopoderoso» $(10,16 ; 51,19)$.

\subsection{Argumentos de moralidad y de bien común}

El profeta también apela al sentimiento moral, para moverlos a convertirse al Dios vivo y verdadero. Con todas sus fuerzas intenta llegar a lo más profundo del alma del pueblo y a su memoria colectiva para denunciar la conducta indigna e inmoral, que se está dando en Judá con la mayor naturalidad e inconsciencia y que desagrada profundamente a Yahvé, porque se aparta de sus designios salvadores.

El interés general también impone la conversión sincera. La supervivencia de Judá, como pueblo, depende de la buena relación con su Dios. Jeremías hace todo cuanto está en su mano para salvar al reino de Judá, moviéndole al cambio e instando a sus paisanos, para que, por una parte, se aparten de los ídolos y se vuelvan a su Dios y, por otra parte, para que no cometan la torpeza de llevar una suicida política antibabilónica. Pero sólo él es consciente del grave peligro que están corriendo. Y la inminente amenaza, cada vez más próxima, le parte el corazón. No logra llevarlos al Dios vivo y verdadero y apartarlos de ídolos inanes y comportamientos vergonzosos ante ellos.

\subsection{Las propiedades divinas}

El monoteísmo de Jeremías queda aún más delimitado, cuando el profeta habla con notable precisión de las propiedades divinas, algunas de las cuales ya hemos mencionado en el transcurso de la exposición: trascendencia, omnisciencia, omnipotencia, justicia, misericordia.

5.4.1. La trascendencia se desprende del dominio absoluto que tiene de la historia. Los imperios no son sino instrumentos en sus manos, como queda de manifiesto sobre todo en los oráculos contra las naciones (cap. 46-51). Yahvé "es el creador de todo» $(10,16)$, sobresaliendo por encima de la creación $(4,24 \mathrm{ss} ; 5,24 ; 10,12)$ y llenando los cielos y la tierra $(23,24)$. Es «el que ha 
puesto el sol para alumbrar el día, la luna y las estrellas para alumbrar la noche; él hace que se encrespe el mar y que bramen las olas, el Señor todopoderoso es su nombre» (31,35). También es el conservador de todas las cosas, "el que implanta en la tierra la fidelidad, el derecho y la justicia» $(9,23)$. Como soberano absoluto de la creación domina la naturaleza $(5,24 ; 10,13 ; 14,22)$ y siembra la vida: "Con mi gran poder y fuerza he hecho la tierra, los hombres y las bestias que hay en ella, y se la doy a quien me place» $(27,5)$.

5.4.2. La omnisciencia presenta varias vertientes complementarias: Yahvé ha dispuesto cuanto existe con gran sabiduría e inteligencia $(10,12)$ y no hay nadie como él entre los sabios de las naciones $(10,6 \mathrm{~s})$. Logra penetrar incluso en lo recóndito del corazón humano $(4,22 ; 23,23 \mathrm{~s})$. Algo que le aparta por completo de los necios dioses, que «son como un espantajo en un melonar, no hablan y hay que llevarlos, porque tampoco andan» $(10,5)$. La contraposición entre Yahvé y los dioses no puede ser mayor y más visible $(10,1-16)$. De ahí que exclame:

«Pero el Señor es el Dios verdadero, el Dios vivo, el rey eterno.

Ante su ira la tierra se estremece, y las naciones no pueden resistir su enojo» $(10,10)$.

5.4.3. La omnipotencia de Yahvé es total. Así lo reconoce el profeta en su impresionante oración: «Eres un Dios grande, que llevas por nombre el Señor todopoderoso; tus planes son grandiosos, tus acciones poderosas» $(32,18$ s). Es capaz de construir y destruir $(4,27 ; 18,7-9)$, participando el profeta, por condescendencia de lo alto, de ese exclusivo poder divino desde los días de su llamada $(1,10)$.

Pero la fuerza omnipotente de Dios, no es ciega o sin rumbo, está atemperada por la justicia $(5,18 ; 9,23 ; 11,20 ; 30,11 ; 32,19 ; 33,16)$ y contrarrestada por la misericordia $(12,15 ; 31,3.9 .20 ; 42,12$; en contra: 13,$14 ; 16,5)$ y la compasión $(3,12 ; 42,12)$. El amor de Dios surge grande $(32,18 ; 33,11.26)$, pero su castigo también se vuelve temible $(32,28)$. De ahí que al profeta se le conmuevan las entrañas, cuando debe anunciar la devastación del país $(4,19 \mathrm{~s})$, debida exclusivamente a los pecados del pueblo.

Considerada su admirable teología, podemos dictaminar que quizá haya sido Jeremías el primer profeta, que recurre a argumentos de la razón y del corazón, para apuntalar la doctrina monoteísta. En sus sentidas y sinceras descripciones del hecho religioso aparecen ya expresiones, que están muy cerca de un monoteísmo teórico estricto, aunque aún no lo expresa con entera claridad en sus afirmaciones. La contundencia total vendrá un poco des- 
pués, en la época final del destierro, coincidiendo con el tiempo de purificación que se produjo en esas trágicas circunstancias y teniendo en cuenta a un hombre providencial de formidable genio teológico. De él queremos hablar ahora.

\section{En la cumbre del monoteísmo: EI Deuteroisaías ${ }^{19}$}

«Son muchos los críticos y exegetas que lo consideran el profeta más grande y el mejor poeta del Antiguo Testamento. También se le reconoce como un extraordinario teólogo» 20 . Ciertamente son admirables su exquisita lírica, los himnos exultantes, los cantos compasivos y su constante dominio del ritmo, las imágenes de extraordinaria hermosura y la gramática. Indudablemente se acredita como un profeta de primera magnitud. Su visión de la trascendencia de Yahvé tiene tal grado de definitividad, que para no pocos estudiosos, entre los que me encuentro, se alza como el profeta monoteísta por antonomasia. Su profecía constituye el primer libro bíblico en el que se habla del monoteísmo de tal modo que ya no deja lugar a dudas como doctrina teológica. En este sentido el cap. 45, con su machacona insistencia, es definitivo:

Yo soy el Señor, y no hay otro;

no hay dios fuera de mí.

Te he dado autoridad,

aunque no me conoces,

para que sepan

de oriente a occidente

que no hay otro fuera de mí;

Yo soy el Señor, y no hay otro.

$(45,5 \mathrm{~s})$
Así dice el Señor, creador del cielo, el Dios que creó la tierra, la hizo y la cimentó;

el que no la creó desierta sino que la hizo habitable: yo soy el Señor y no hay otro. pues yo soy Dios y no hay otro.
¿No fui yo, el Señor? no hay otro dios fuera demí... Yo soy un Dios fiel y salvador, y no existe ningún otro. Volveos a mí y os salvaréis, confines de la tierra,

(45,21s: cf. 46,9).

Ante tanta belleza de expresión se repite un estribillo machaconamente: «Yo soy el Señor, y no hay otro» con fuertes aires de verdad. La expresión lin-

19 Para una bibliografía internacional bastante completa, cf. D. MiCHEL, «Deuterojesaja» en $T R E 8,528-530$. Una bibliografía en castellano, que nos permite integrar al Deuteroisaías en su contexto político, social, cultural y sobre todo religioso, puede verse en: H. SIMIANYofre, Isaías. Texto y comentario (El mensaje del Antiguo Testamento 12; Madrid 1995; Casa de la Biblia) 31. Ha aparecido también en: Id, «Jeremías», en S. GuIJARRo/ M. SALVADOR (dir.), Comentario al Antiguo Testamento II (Madrid 21997; Casa de la Biblia). Puede completarse con B. MARCONCINI, El libro de Isaías (40-66) (Guía Espiritual del AT; Madrid 1999). teban) 121 .

20 R. GonzÁlez Blanco, Los profetas, traductores de Dios (Salamanca 2004; San Es- 
güística adquiere una forma definitiva. El mensaje no puede tener mayor contundencia. Los preciosos himnos frecuentes no sirven ya de relleno o transición, sino que son elementos, que estructuran el discurso y marcan lo más significativo de lo que el profeta quiere expresar: la exclusividad de Yahvé en el ámbito teológico. La incomparabilidad de su proceder con el resto de los seres por excelsos que parezcan. El profeta escribe al final de la Cautividad de Babilonia. Ya conoce el edicto de Ciro, que permite a los judíos volver a su patria. Su investidura puede considerarse como acción del Señor $(45,1-8)$, que utiliza su reinado para liberar a su pueblo (45,9-13).

El Deuteroisaías transmite entonces a los suyos una buena noticia, transida de consolación. Su Dios nacional se alza como el único Dios, no hay otro. Se acredita como el Santo de Israel ${ }^{21}$. Nada tiene que ver con Marduk, el dios principal de los babilonios, ni con sus ídolos inhumanos y vacíos. Su potencia regeneradora trasciende todo lo existente. De hecho Yahvé brilla como el solo Creador y Salvador. Ha puesto su inmenso poder en beneficio de su pueblo, dispuesto a realizar una nueva creación. El Señor, que renueva constantemente cuanto desea, va a realizar con los suyos un nuevo éxodo. Por eso han de prepararse al tiempo de gracia que irrumpe como nueva creación.

La cautividad no ha sido culpa de Yahvé, debido a su ineficacia ante el poder de los dioses de los vencedores 22 , sino el resultado ineludible del pecado de Judá e Israel. Pero una vez satisfecha la culpa, Dios desea convertir la vuelta a la tierra dada, como una marcha triunfal con disposición jubilosa y cantos de liberación. El momento no puede tener perspectivas más entusiasmantes. Por eso la profecía del Deuteroisaías está transida de la positividad de la salvación. Más que ninguna otra, ya que detrás de ella se alza la acción imponente del único Dios. En su profecía no encontramos reproches contra Israel, como en los otros profetas, sino permanentes anuncios de salvación y llamadas incesantes al consuelo. De ahí que su escrito haya sido llamado, con

21 Yahvé es el único santo, repite con frecuencia el profeta. Todos los demás lo son por participación. Ha entrado en relación con Israel y por eso Israel es santo (Ex 19,6). En este tema, el Deuteroisaías depende del Protoisaías (cf. 41,14.16.20; 43,3.14; 47,4; 48,17; 49,7; 54,5; $55,5)$. En nuestro profeta la idea de la santidad de Yahvé aparece combinada con la de «Redentor» «Libertador» $(41,14 ; 54,5)$.

22 «Esta cosmovisión religiosa que une el poderío político-militar del pueblo a las capacidades de su dios, es una idea común en los pueblos del medio oriente antiguo. La nación vencedora es más grande y mejor que la vencida, del mismo modo, el dios vencedor lo es respecto del perdedor. Toda esta problemática no se plantea en abstracto, surge a partir de un desastre nacional: la caída de Jerusalén (587 a. C.) y la consiguiente deportación que duró hasta el 538 a. C. Al producirse la destrucción de la ciudad santa y el destierro de Judá a Babilonia, se pone en entredicho la relación de Dios con su pueblo y, más aún, la misma imagen de Dios cuya capacidad para liberar no parece ser clara» (ibídem, 122). 
toda justicia, «El Libro de la Consolación». El inicio de gran belleza y fuerza expresiva es bien sintomático:

«Consolad, consolad a mi pueblo,

dice vuestro Dios,

hablad al corazón de Jerusalén

gritadle que se ha cumplido su condena

y que está perdonada su culpa,

pues ha recibido del Señor

doble castigo por todos sus pecados» $(40,1)$.

Esta constatación nos lleva a formular que en todo el Primer Testamento no existe un texto que sea tan coherente y taxativo en la exposición de la tesis de que a partir de ese momento sólo se puede pensar en la reconstrucción y gozar de la salvación, porque el único Dios patrocina la restauración. Cuando, por ejemplo, habla de la ceguera y sordera de Israel $(42,18 \mathrm{ss})$, no es para lanzar reproches, sino para abrir al pueblo con más insistencia al Dios Salvador:

«El Señor quería manifestar

su.salvación

y hacer grande y gloriosa

su enseñanza» $(42,21)$.

"Y ahora, así dice él Señor;

el que te creó Jacob;

el que te formó, Israel:

No temas, que yo te he rescatado,

te he llamado por tu nombre

$y$ eres mío» $(43,1)$.

"Yo; yo soy el Señor;

fuera de mí no hay salvador.

Yo lo anuncié, os salvé y lo proclamé» $(43,11$ s).

Cabe destacar que precisamente en este contexto de perdón y salvación, es cuando resuena su mensaje acerca del monoteísmo. Aunque algunos de sus bellos himnos parten de la existencia de muchos dioses, el profeta sabe cambiar de signo el rumbo doctrinal, cuando habla de que los dioses son sometidos a un juicio cósmico. En el curso del proceso queda sobradamente probado, que los dioses no tienen ninguna influencia en la historia y carecen de capacidad de salvar a los humanos. No pueden predecir el futuro tanto el cósmico como el humano. El resultado no puede ser más desolador para aquellos: No obran, ni deciden; en realidad no poseen fuerza alguna, no sirven para 
nada. No existen como dioses, sino como hechura de hombres débiles. Habla así de dos de ellos:

«Bel cae por tierra,

Nebo se doblega.

Sus imágenes son cargadas

sobre bestias y acémilas:

Los llevan como fardos

sobre animales desfallecidos» $(46,1)$.

Los ídolos son inútiles, no tienen consistencia alguna (44,9-20). Los que corren detrás de ellos no pueden adquirir la salvación, están atrapados en su ridiculez. El insensato «se fabrica un dios y lo adora, se hace un idolo y se postra ante él. Con la mitad hace lumbre, y sobre las brasas asa carne; luego se la come, queda satisfecho, se calienta y dice: "Qué bien tengo luz y calor". Y con lo que queda se hace su dios, su idolo. Se postra en adoración ante él, y le reza: "Sálvame, que tú eres mi dios". No saben ni entienden nada. Tienen ofuscados la vista y la mente y no ven ni entienden. Son incapaces de reflexionar, no tienen sentido ni inteligencia para pensar [...]. Son insensatos que se dejan seducir por algo que puede convertirse en ceniza. No se salvarán, pues no se dan cuenta de que es puro engaño lo que tienen en las manos» (44,15-20).

En este contexto Yahvé puede expresar esta autoalabanza, que corresponde a la verdad más auténtica:

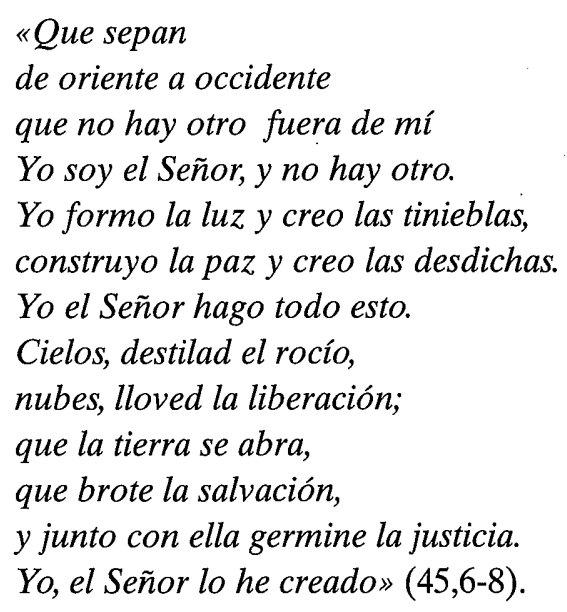

Aquí ya no aparecen para nada los dioses. Sólo Yahvé preside la realidad de la creación, porque ha formado y sostenido todo, porque acompaña lo existente con sabiduría y justicia. Su providencia confiere consistencia a lo crea- 
do. Yahvé se alza como el único Señor, sin posibilidad de que haya otro. Los judíos pueden contemplar su historia con esperanza, de toda ella destila gracia y salvación:

«Escuchadme,

Los que vais tras el Señor,

Los que buscáis la salvación.

Mirad la roca

De la que fuisteis tallados,

La hondura

De la que fuisteis extraídos;

Mirad a vuestro padre Abrahán,

Y a Sara, que os dio a luz.

Estaba solo cuando lo llamé,

Pero lo bendije y lo multipliqué.

Del mismo modo consuela el Señor

A Sión y a sus ruinas» (51,1-3).

Las naciones paganas pueden alcanzar también la salvación, ya que la justicia y el derecho de Yahvé ilumina a todos, su salvación alcanza a quienes confían en su poder e inteligencia. La acción divina adquiere así ahora un alcance universal, que no pasa, como sucede con las cosas creadas. Tanto los pueblos cercanos como los lejanos están afectados por la acción salvadora del único Dios.

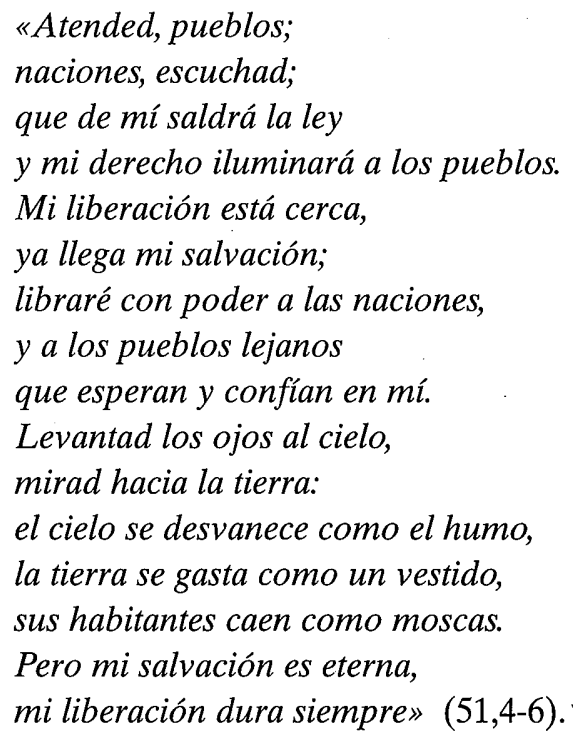


En las postrimerías del Destierro de Babilonia, el Deuteroisaías piensa ya de forma totalmente monoteísta en Yahvé, a quien con frecuencia, ya lo hemos anotado, llama «el Santo de Israel, el salvador» $(43,3)$. Su profecía contiene un monoteísmo teórico, que no deja lugar a dudas y que hasta entonces en la historia de la humanidad no se había escuchado mensaje semejante. Nadie se puede comparar a Yahvé, nadie posee su grandeza. Su sabiduría y fuerza y su poder no encuentran rival.

Una tríada de constataciones apuntalan este monoteísmo teórico: a) la incomparabilidad de Dios, b) su trascendencia absoluta y c) su poder creador y salvador; realidades que en su conjunto convergen en el único Yahvé. Precisamente contemplando la naturaleza $(40,21-26)$ y observando la historia (41,1-7), es como el gran profeta consigue «la prueba» de la insondable omnipotencia de Dios y la no existencia de los dioses. Yahvé, que no tiene genealogía, se encuentra en el origen de todo:

"Antes de mí no fue formado ningún dios

y ninguno existirá después.

Yo; yo soy el Señor;

fuera de mí no hay salvador» $(43,10 \mathrm{~s})$.

"Yo soy Dios;

lo soy desde siempre,

y nadie puede libraros de mi mano.

Lo que yo hago, ¿quién lo puede deshacer? $(43,12 \mathrm{~s})$.

Desde ahora los judíos tienen la posibilidad de pensar de forma monoteísta, entender que Dios es el Absolutamente Otro, comprender el sentido de la creación y ponderar la impresionante salvación, que procede de un solo amor. Aún falta la formulación exacta, que precise el concepto totalmente. Esto ocurrirá, cuando el judaísmo, al final del siglo $I V$ antes de Cristo, entre en contacto con la lengua griega. Entonces se precisará el concepto de forma

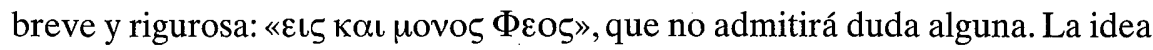
judía es ahora formulada con la exacta precisión. El monoteísmo es judío; la precisión terminológica, griega.

\section{CONCLUSIONES:}

1. En la actualidad la mayoría de los especialistas mantienen la tesis de que el monoteísmo «fue una evolución relativamente tardía, en la que influ- 
yó de manera decisiva la actividad profética» ${ }^{23}$. En efecto, el monoteísmo constituye uno de los grandes conocimientos nuevos, que los profetas legaron al pueblo de Israel y en él a la humanidad entera. Ilumina las conciencias, estructura el pensamiento de forma coherente y educa en el sentido de la realidad diaria. De su herencia participamos, conviene recordarlo y agradecerlo, de un modo especial los cristianos. En relación con el tema desarrollado hasta aquí, ¿en qué consiste la aportación de los profetas? Éstos han descubierto algo decisivo en la revelación, que Dios ha querido manifestarles no sólo a ellos, sino también a cada uno de nosotros, cuando entramos en contacto con sus oráculos y acogemos sus enseñanzas. Los profetas nos han ayudado a descubrir un aspecto central de esa revelación, adquirido con progresivo esfuerzo. Por derecho propio su significación adquiere un alcance universal.

Yahvé es el único Dios, el verdadero Dios. Por lo tanto existe un solo Dios, Hacedor de los cielos y de la tierra y Señor del universo entero, que tiene especial predilección por los humanos. Se comporta como Creador y Salvador. Sólo Dios es Dios y únicamente la divinidad de Dios es digna de ser adorada, entregando al Altísimo por entero el corazón. Nos recuerda el salmista, con el mismo espíritu del Deuteroisaías: « Rendíos, reconoced que yo soy Dios, encumbrado sobre los pueblos, encumbrado sobre la tierra!» (Sal 46,11 ). Los profetas manifestaron esta variopinta confesión progresivamente con palabras, signos y sobre todo con el testimonio veraz de su vida entregada. Sus palabras van apoyadas por una vida santa, que hace más sincero y valioso el conocimiento legado.

2. Vuelve a tener razón LOHFING, cuando afirma que el monoteísmo teórico en sentido propio «no es conocido hasta el exilio babilónico» 24 y no logró imponerse entre los hebreos hasta la época persa ${ }^{25}$, en las postrimerías del siglo sexto antes de Cristo. Sólo desde entonces la fe judía fue monoteísta. Podemos considerar al Deuteroisaías como el primer profeta estrictamente monoteísta de la Biblia. Desde su bellísimo y realísimo mensaje los judíos están capacitados para pensar de una manera nueva la realidad única del Dios Uno.

23 R. J. ZWI Werblowsky, «Judaísmo» en C. J. BLEEKER/ G. WIDENGREN (ed.), Historia Religionum. Historia de las Religiones II. Religiones del presente (Madrid 1973; Cristiandad) 13.

24 N. LoHfink, Unsere grossen Wörter. Das Alte Testament zu Themen dieser Jahre, 131: «Und es lässt sich andererseits zeigen, dass Israel bis ins Babylonische Exil einen theoretischen Monotheismus im üblichen Sinn nicht gekannt hat».

25 «Theoretischen Monotheismus wird es erst von der Persenzeit an geben» (N. LoHFink, Unsere grossen Wörter. Das Alte Testament zu Themen dieser Jahre, 113). 
Pocas veces un momento histórico concreto se ha hecho tan universal como el vivido por el profeta anónimo, que está detrás de Is 40-55. Lo que expone el conocido como «el Isaías del Destierro», el formidable teólogo y el gran poeta, posee tal trascendencia antropológica y teológica, adquiere tal significación para el monoteísmo, que se ha convertido en algo difícilmente superable. Ha dejado una huella imperecedera e inolvidable. Lo que afirma en estos capítulos sobre el monoteísmo tiene belleza, desprende verdad y deja un halo de perennidad. Ha marcado la experiencia religiosa posterior tanto del judaísmo como del cristianismo e islamismo.

3. Pero conviene que entendamos bien el sentido exacto del monoteísmo. El Dios uno y único no es un solitario, aislado en su magnificencia. Más bien es una Presencia Viva, cuyo amor sostiene lo creado, protege a los humanos y concierne también a mi vida. El monoteísmo sitúa a Dios en el centro de la orientación de la existencia humana, en el fundamento de la esperanza, que apunta hacia la bienaventuranza final. Creer en el Dios único significa entonces buscar el origen de todo en su actuación viva y eficaz y centrar la existencia humana en su providencia amorosa, visible a los ojos de la fe. Los dos grandes colosos del monoteísmo, Jeremías y el Deuteroisaías, engarzan con pleno acierto el monoteísmo con la creación y la salvación. Todo encuentra su principio en Dios, que no sólo crea, también redime y salva a los hombres con la fuerza de su amor.

4. Como hemos indicado, al hablar sobre todo del Deuteroisaías, descubrir el monoteísmo significa mostrar la verdad del amor apasionado de Dios; que en el cristianismo se convierte en amor trinitario: amor insondable del Padre en el Hijo por el Espíritu Santo. El monoteísmo no entraña en sí mismo violencia, como algunos quieren hacernos creer, sino derroche de amor generoso y tributo de aceptación gozosa de la oferta amorosa divina. Son muchos hoy los que, en los países de la Europa Unida, piensan que uno de los mayores males, que ha tenido Occidente a lo largo de su historia, la violencia intolerante, tiene su origen en el monoteísmo de la herencia judeo-cristiana; idea falaz, por cierto, que queremos rechazar aquí con la mayor de las decisiones.

«La teología, en fecundo diálogo con la filosofía -ha comentado Benedicto XVI hace muy poco en conversación con la Comisión Teológica Internacional-puede ayudar a los creyentes a tomar conciencia y a testimoniar que el monoteísmo trinitario nos muestra el verdadero Rostro de Dios, y este 
monoteísmo no es fuente de violencia, sino de paz personal y universal» ${ }^{26}$. La última frase no puede ser más significativa, ya que desautoriza esa extendida creencia que hemos mencionado, existente entre no pocos intelectuales europeos, de que los grandes conflictos de la sociedad occidental tienen su raíz en el monoteísmo judeo-cristiano. Y precisamente lo contrario es el caso: el «monoteísmo no es fuente de violencia, sino de paz personal y universal», volvemos a repetirlo. Podemos afirmar sin equivocarnos que el monoteísmo profético, del que participa también Jesús, alimenta una religiosidad reconciliada, del uso de la razón, y de una razón que concuerda con la sana religión ${ }^{27}$.

Ciertamente ha habido demasiados momentos en la historia de la humanidad, y por lo que a nosotros nos interesa también en la convulsa historia de Occidente, en los que la religión se ha aliado con la violencia y ha producido efectos devastadores. No ha sabido mantenerse como fuente de paz y de verdad. Tampoco se ha despojado de violencias y ha testimoniado el amor divino, estando a la altura de las circunstancias ${ }^{28}$. Pero la violencia constituye una degeneración, no pertenece a la esencia misma de la religión y mucho menos de la cristiana, que es fraternidad, familia de hijos y hermanos. Tampoco pertenece al auténtico monoteísmo bíblico de cuño profético.

Ciertamente en nombre del monoteísmo, como momento cumbre de la religión, se ha recurrido falsariamente a la violencia en la historia. Pero siempre que ha sucedido, se ha debido a un abuso de sus limites y ha traspasado, por exceso o desmesura, lo que significa la verdadera religión, lo que consiste creer en un solo y único Dios, que en el cristianismo se despliega en una trinidad de personas.

\footnotetext{
26 Roma 2.12.11.

27 En su libro Radical Monotheism and Western Culture (1960), el teólogo americano H. Richard NIEBUHR (1894-1962) distingue y contrasta en nuestra época el henoteísmo del monoteísmo de un modo original y profundo. En un sentido moderno, el henoteísmo expresa la exaltación de un grupo por encima, y a veces, con exclusión de los demás. En el desarrollo de esta corriente pueden incluirse el racismo, nacionalismo, fascismo, nazismo, comunismo con sus actos violentos para lograr imponerse. El monoteísmo, sin embargo, afirma la existencia de un solo Dios como fuente de todos los valores. Una sociedad monoteísta es una sociedad abierta, sin que se privilegie a ningún grupo concreto. De ahí que la religión del Primer Testamento conceda gran valor al extranjero y Jesús privilegie el amor al prójimo. Sostiene concretamente: «It [i.e., radical monotheism] is the confidence that whatever is good, is good, because it exists as one thing among the many, which all have their origin and their being, in the One-the principle of being which is also the principle of value» (p. 6). Además aboga por un enfoque integrador de la cultura, la política, la ciencia y la religión.

28 Este hecho fatídico y hasta trágico lo ha recordado también Benedicto XVI en el encuentro de Asís del 27.10.11. Cf. Ecclesia n 3596 (2011) 27.
} 
5. Puede sorprender el que afirme que el monoteísmo tiene que salir al paso del politeísmo, también del ateísmo con tolerancia, intentando ir más allá de las palabras e indagando en la realidad misma, que es más honda de lo que a simple vista puede parecer. Ciertas formas de ateísmo en realidad no niegan la existencia de cualquier forma de trascendencia sin más. Lo que rechazan son las formas concretas, cómo se ha mediado la idea de Dios en las culturas y tradiciones religiosas y que no siempre han sido las más certeras. El politeísmo, por su parte, puede consistir en una manera de aproximarse a Dios, en la que se trasciende lo universal, para dar sentido, incluso permanencia a lo local, lo concreto de la realidad más cotidiana en la que Dios también se puede manifestar. Pero conviene recordar que también a través de esas formas religiosas deficientes se puede experimentar algo del Dios vivo y verdadero.

6. Todo lo que sea querer entender más allá de las palabras, de la literalidad de las confesiones de fe bien estructuradas, para tratar de captar lo íntimo y profundo, que se esconde en el corazón humano, puede ser una manera de acercamiento a Dios vivo y verdadero, que puede servirnos para expresar la realidad divina, de la que tanto depende el progreso humano y la felicidad de la humanidad. Lo que los profetas nos propusieron en su mensaje sobre el monoteísmo consiste en mostrar que detrás de la realidad de Yahvé, el Dios nacional del pueblo de la promesa, el que acompaña en todas las circunstancias, el que garantiza su presencia aun en las condiciones más adversas, existe una realidad inefable, que difícilmente puede verbalizarse; realidad que importa al hombre más que nada y nadie. En la aceptación de esa realidad el hombre se juega el presente y el futuro. Lo existente está cargado de positividad, una positividad que el hombre puede hacer suya, cuando se acerca respetuosamente a ella con buena disposición, con memoria agradecida, incluso con júbilo y acción de gracias. Cuando detrás de ella, contempla al Dios vivo, que garantiza todos los valores, que ennoblecen a las personas.

Tener los ojos abiertos, obedecer la realidad tal como es, significa la posibilidad de abrirse a la trascendencia, que nos ayuda a descubrir que el hombre no logra su vida, cuando se encierra en sí mismo, sino cuando con sinceridad, honestidad y responsabilidad se abre a aquella realidad que es más grande que él, que le precede en el amor; y en cuya aceptación se dirime su presente y se decide su futuro, recordando un pasado abierto, que se puede volver a revivir en el presente por su significatividad y trascendencia. En realidad el monoteísmo, bien entendido, nos ayuda a ser más humanos, ya que el único Dios abre a todos la salvación con una misma dignidad, los mismos derechos e iguales garantías. 
7. Dejo a un lado temas importantes como el lenguaje adecuado para acercarnos al misterio de Dios, el uso del simbolismo para salir al encuentro de la trascendencia. Al finalizar mi aportación sólo quisiera recordar algo decisivo para completar el tema abordado. «A Dios nadie lo ha visto jamás; el Hijo unigénito, que está en el seno del Padre, es quien lo ha dado a conocer» (Jn 1,18).

Aunque de Dios desconocemos mucho más que conocemos, aunque nuestro lenguaje sobre Dios es aproximado, metafórico e inapropiado siempre, Jesucristo el Mesías, el Hijo del Padre nos ha descubierto el Rostro Verdadero de Dios Uno y Único, en una certera dimensión, que puede llenar la vida humana de sentido y encaminarla hacia la eternidad ${ }^{29}$. Somos sostenidos por el amor irrevocable del Padre bueno, que en el Hijo y por inspiración del Espíritu Santo nos ama apasionadamente como a hijos queridos en una comunidad de hermanos. Cuanto más nos introducimos en el misterio infinito de ese insondable amor divino, más gozo inunda nuestra existencia y más cerca estamos de la felicidad imperecedera. El monoteísmo trinitario, que para los cristianos constituye la culminación de la revelación, tiene mucho de verdad y belleza, pero sobre todo de amor y salvación.

29 Cf. R. Bauckham, El Dios crucificado: Monoteísmo y cristología en el Nuevo Testamento (Barcelona 2003; Clie). 